\title{
The Place of Nailfold Capillaroscopy Among Instrumental Methods for Assessment of Some Peripheral Ischaemic Syndromes in Rheumatology
}

\author{
Sevdalina N. Lambova \\ Department of Propedeutics of Internal Medicine, Faculty of Medicine, Medical University of Plovdiv, Plovdiv, Bulgaria
}

\author{
Correspondence: Sevdalina Lam- \\ bova, Department of Propedeutics \\ in Internal Medicine, Faculty of \\ Medicine, Medical University of \\ Plovdiv, Plovdiv, 15A Vassil Aprilov \\ Blvd., 4002 Plovdiv, Bulgaria \\ E-mail: sevdalina_n@abv.bg \\ Tel: +359889560104
}

Received: 9 March 2016

Accepted: 4 May 2016

Published: 30 June 2016

Key words: Raynaud's phenomenon, blue toe syndrome, rheumatic diseases, microcirculation; nailfold capillaroscopy

Citation: Lambova SN. The Place of Nailfold Capillaroscopy Among Instrumental Methods for Assessment of Some Peripheral Ischaemic Syndromes in Rheumatology.

Folia Medica 2016;58(2);77-88, doi: 10.1515/folmed-2016-0011
Micro- and macrovascular pathology is a frequent finding in a number of common rheumatic diseases. Secondary Raynaud's phenomenon (RP) is among the most common symptoms in systemic sclerosis and several other systemic autoimmune diseases including a broad differential diagnosis. It should be also differentiated from other peripheral vascular syndromes such as embolism, thrombosis, etc., some of which lead to clinical manifestation of the blue toe syndrome.

The current review discusses the instrumental methods for vascular assessments. Nailfold capillaroscopy is the only method among the imaging techniques that can be used for morphological assessment of the nutritive capillaries in the nailfold area. Laser-Doppler flowmetry and laser-Doppler imaging are methods for functional assessment of microcirculation, while thermography and plethysmography reflect both blood flow in peripheral arteries and microcirculation. Doppler ultrasound and angiography visualize peripheral arteries. The choice of the appropriate instrumental method is guided by the clinical presentation. The main role of capillaroscopy is to provide differential diagnosis between primary and secondary RP. In rheumatology, capillaroscopic changes in systemic sclerosis have been recently defined as diagnostic. The appearance of abnormal capillaroscopic pattern inherits high positive predictive value for the development of a connective tissue disease that is higher than the predictive value of antinuclear antibodies. In cases of abrupt onset of peripheral ischaemia, clinical signs of critical ischaemia, unilateral or lower limb involvement, Doppler ultrasound and angiography are indicated. The most common causes for such clinical picture that may be referred to rheumatologic consultation are the antiphospholipid syndrome, mimickers of vasculitides such as atherosclerosis with cholesterol emboli, and neoplasms.

\section{INTRODUCTION}

Micro- and macrovascular pathology is a common feature in a number of common rheumatic diseases. Reliable diagnostic tools should be used in order to guide physicians in the differential diagnosis and administration of well-timed treatment that would improve prognosis, slow up or prevent future damage or provide full recovery in cases of medical emergency.

\section{AIM}

The present review discusses the instrumental methods for vascular assessment. Two case reports are presented to illustrate the possibilities of the imaging modalities in clinical context.

\section{RESULTS}

\section{RAYNAUD'S PHENOMENON}

Raynaud's phenomenon (RP) is among the most common symptom in systemic autoimmune diseases. It manifests as reversible vasospasm of the small peripheral arteries and arterioles at cold exposure or emotional stress. It presents in three or two phases e. g., ischaemia, asphyxia and reactive hyperemia with skin discolouration from pallor to cyanosis and redness with clearly visible demarcation line. It affects acral body parts such as fingers, toes, nose, ears, lips. RP could be idiopathic or primary, when there is no underlying cause for its development and the clinical course is benign without development of trophic changes because of the lack of endothelial 
damage. Secondary RP is observed in a number of connective tissue diseases and includes a broad differential diagnosis including drug-induced RP and paraneoplastic conditions. The profound endothelial damage may lead to appearance of digital ulcers in a proportion of cases with secondary RP. ${ }^{1-4}$ It should be also differentiated from other peripheral vascular syndromes such as embolism, thrombosis, etc., some of which lead to clinical manifestation of the blue toe syndrome. A number of laboratory and instrumental methods are essential for the differential diagnosis. Interpretation of the findings is in the concrete clinical context.

$\mathrm{RP}$ is diagnosed clinically. The diagnosis is based on the direct observation of 2 among the 3 possible phases of the condition. To be diagnosed with RP, a patient should have a history of sensitivity to the cold and episodic pallor, cyanosis or redness of the distal portions of the digits after exposure to cold. Photographs of the hands may be obtained during an attack and used to confirm the history. In routine clinical practice it is not necessary to perform a cold provocation test to make a definitive diagnosis of RP. ${ }^{5}$

\section{BLUE TOE SYNDROME}

The term 'blue toe syndrome' describes the development of blue or violaceous discoloration of one or more toes in the absence of obvious trauma, serious cold-induced injury, or disorders producing generalized cyanosis. The condition may develop in cases of micro-, macrovascular pathology, impaired venous outflow and hyperviscosity syndromes. Three major categories are recognized:

1. disorders with decreased arterial flow - arterial obstruction due to:

- embolism (atheroemboli due to spontaneous plaque haemorrhage or induced by different provoking factors, cardiac or aortic tumor, infective endocarditis);

- thrombosis (antiphospholipid syndrome, malignancy (paraneoplastic acral vascular syndrome, disseminated intravascular coagulation, warfarin skin necrosis);

- vasoconstrictive disorders (acrocyanosis, chilblains, drug induced vasoconstriction, infectious and non-infectious vessel inflammation;

2. impaired venous outflow (venous thrombosis);

3. abnormal circulating blood (paraproteinemia with hyperviscosity, myeloproliferative disorders, cryofibrinogenemia, cryoglobulinemia).

Prevalence of atheroembolism is increased due to the higher use of different vascular interventions such as vascular surgery or invasive percutaneous procedures i.e., angiography and angioplasty. In addition, anticoagulant therapy could also induce this iatrogenic complications. ${ }^{6}$

A number of instrumental techniques are used to assess microcirculation in patients with symptoms of RP in order to prove the presence of vascular pathological changes and to differentiate the primary from secondary forms of the disease that is crucial for the therapeutic approach such as nailfold capillaroscopy, laser Doppler flowmetry, laser Doppler imaging, thermography at rest and in combination with cold provocation. Colour Doppler and angiography are additional instrumental techniques that visualize larger vessels and facilitate the differential diagnosis in more complex cases of peripheral vascular ischaemic pathology.

Nailfold capillaroscopy is the only method for morphological assessment of nutritive capillaries. Laser Doppler and thermography assess cutaneous blood vessel function. ${ }^{7}$

\section{RAYNAUD'S PHENOMENON IN RHEUMATIC DISEASES}

$\mathrm{RP}$ is a characteristic feature in a number of rheumatic diseases with substantially high frequency in systemic sclerosis (SSc) - approximately $90-95 \%$ (Table 1). ${ }^{8,9} \mathrm{RP}$ in $\mathrm{SSc}$ is a clinical manifestation of vasospasm of the peripheral digital arteries and arterioles as well as of permanent structural endothelial damage of the microcirculation that is associated with the high rate of development of digital ulcers in these patients in over half of the cases. ${ }^{10}$ In $100 \mathrm{SSc}$ patients, La Montagna et al. (2002) found that symptoms of RP of the feet are present in $90 \%$ of the cases vs $100 \%$ frequency of RP at the hands. In $43 \%$ of the cases from this group, RP of the feet was presented at initial evaluation, while $47 \%$ developed it in the course of the follow-up. In contrast, RP of the hands was registered in $100 \%$ of patients at the initial evaluation. The onset of clinically evident involvement of the feet was found to occur later in limited SSc than in the diffuse form of the disease. Lower rate of necrotizing RP was found in the feet of patients with SSc as compared with the hands. ${ }^{11}$

Among other common rheumatic diseases, the prevalence of RP in systemic lupus erythematosus varies between 10 and $45 \%$ and it usually indicates a more benign course without tissue necrosis. ${ }^{8,12}$ 
Table 1. Common differential diagnosis of Raynaud's phenomenon in rheumatologic practice.

Systemic sclerosis

Mixed connective tissue disease

Undifferentiated connective tissue disease

Systemic lupus erythematosus

Dermatomyositis, polymyositis

Sjögren syndrome

Rheumatoid arthritis

Systemic vasculitides - Buerger disease, Takayasu arteritis, polyarteritis nodosa, granulomatosis with polyangiitis, etc.

Other common conditions that are associated with Raynaud's phenomenon and are included in the differential diagnosis in rheumatologic practice

Drug-induced Raynaud's phenomenon - beta blockers, cytotoxic drugs - vinblastine, bleomycin, interferon, etc.

Paraneoplastic Raynaud's phenomenon - associated with solid tumours and haematological malignancies.

RP occurs in over $75-96 \%$ of patients with mixed connective tissue disease (MCTD) that is characterized with a specific immunologic marker anti-U1- RNP antibody. Due to its high frequency, $\mathrm{RP}$ is included in the currently used classification criteria for MCTD (the criteria of Allargon - Segovia and Villareal, Kasukawa et al., Sharp, Kahn). Development of trophic changes of the fingers is a frequent complication in these patients. ${ }^{12,13}$

In undifferentiated connective tissue disease (UCTD) patients, features of systemic rheumatic disease are present, but there is not a full set of characteristics of a well-defined rheumatic disorder. $\mathrm{RP}$ is a frequent symptom that may be observed in about $80 \%$ of the cases. During a longer period of follow-up, a part of these patients $(1 / 4$ to $1 / 3)$ develop a distinct rheumatic entity, the most frequent being SSc, SLE, rheumatoid arthritis (RA), Sjögren syndrome, but the majority of patients remain in a clinically and laboratory stable condition in the scope of the term UCTD. In some of these patients (1/4 to $1 / 3)$, Nagy et al. found a scleroderma-like capillaroscopic pattern in $13.8 \%$ of 65 patients with "UCTD". ${ }^{14}$ In our own study of 31 UCTD patients, we have found a frequency of RP $78 \%$, and in $38 \%$ of cases a scleroderma-like pattern at capillaroscopic examination was observed. ${ }^{15,16}$

The prevalence of RP in RA is not well-defined. Some authors consider that such an association is quite rare ${ }^{9}$, while other authors include RA among the rheumatic diseases associated with $\mathrm{RP}^{8,17}$. Grassi et al. (1994, Italy) found a low incidence of RP in RA $-4.6 \%,(19 / 411)$. The higher prevalence of
$\mathrm{RP}$ in men with RA (7.5\%) than in women (3.2\%) was interesting. In comparison, in a cohort of 919 patients with osteoarthritis, a global tendency of a female predominance of RP was observed. The higher prevalence of RP in men with RA was explained by the authors with a stronger association of RA with secondary vasculitis in men. ${ }^{18}$ These results are in agreement with the findings of Carrol et al. (1981, North Australia), who found a manifestation of RP in $2.7 \%$ of 141 patients with RA. ${ }^{19}$ In a French population of RA patients, Saraux et al. found a higher prevalence of RP in RA $(17.2 \%, 54 / 322) .{ }^{20}$

\section{NAILFOLD CAPILLAROSCOPY}

The main indication for nailfold capillaroscopic examination in rheumatology is presence of RP. The method is of crucial value for the differential diagnosis of primary and secondary RP in rheumatic diseases. The capillaroscopic pattern in healthy subjects remains unchanged for prolonged periods of time. The normal capillaroscopic pattern is characterized with hair-pin shaped capillary loops with regular distribution and parallel orientation. In each dermal papilla there are one to three capillary loops (Fig. 1). ${ }^{15,21}$

Capillaroscopic examination reveals specific changes in SSc - the so-called scleroderma type capillaroscopic pattern, which is a reference pattern in rheumatology. It was described for the first time by Maricq et al. (1980) 22 and is characterized by dilated, giant capillaries, haemorrhages, avascular areas, and neoangiogenic capillaries. It is observed in the majority of SSc patients analogous to the 


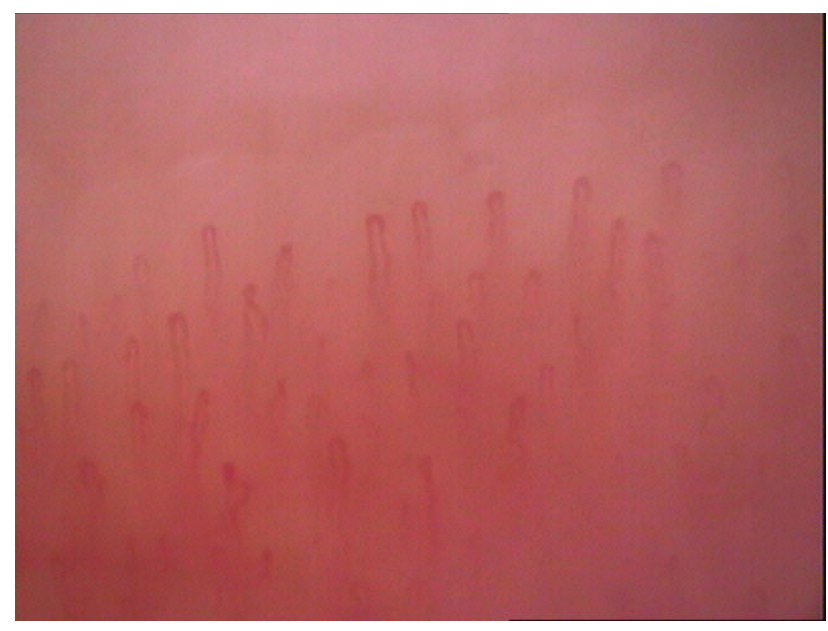

Figure 1. Capillaroscopic pattern in a healthy subject hair-pin shaped capillary loops with regular distribution and parallel orientation.

high frequency of RP (in more than 90\%). ${ }^{15,21}$

Cutolo et al. (2000) recognized three phases of capillaroscopic changes in SSc:

1. an "early" phase, which is characterized with few dilated and/or giant capillaries and few haemorrhages. Avascular areas do not exist and the capillary distribution is preserved.

2. In the "active" phase, numerous giant capillaries and haemorrhages, a moderate capillary loss and derangement are present. In addition, pericapillary oedema could be found.

3. In the "late" phase, there is severe loss of capillaries and capillary derangement as well as evidence of neoangiogenesis with bushy and ramified capillaries. $^{23}$

The capillaroscopic changes develop in the early stages of SSc even before the establishment of the definite diagnosis. To improve the early diagnosis of SSc, Le Roy and Medsger proposed patients with RP and abnormal nailfold capillaroscopic changes or positive specific for SSc autoantibodies to be diagnosed as pre-scleroderma or limited SSc even in the absence of other manifestations of the disease (Le Roy and Medsger, 2001). ${ }^{24}$

More recently, the capillaroscopic changes are defined as diagnostic for SSc according to the new classification criteria of European League Against Rheumatism (EULAR) and American College of Rheumatology (ACR) (2013) in order to improve the possibilities for early and very early diagnosis of the disease. According to the new EULAR/ACR classification criteria for $\mathrm{SSc}$, definitive diagnosis is established if the patient's total score is $\geq 9$, and capillaroscopic changes are scored with 2 points.
Presence of RP is scored with 3 points and positive SSc-related autoantibodies (anti-centromere, antiScl-70 and anti-RNA polymerase III) with 3 points (maximum score 3 for the whole section). ${ }^{25,26}$

The normal capillaroscopic pattern is a diagnostic criterion for primary RP (Le Roy and Medsger, 1992). For the diagnosis of primary RP, the lack of the following criteria (Le Roy and Medsger) is required: a) digital ulcerations and gangrenes; b) elevated erythrocyte sedimentation rate; c) positive test for antinuclear autoantibodies (ANA) with a high titer; d) abnormal capillaroscopic pattern. ${ }^{17}$ Capillaroscopic pattern in primary RP is not specific and the demonstrated capillaries are normal in number and size. The mean capillary diameter, capillary density and capillary morphology do not differ significantly from those of healthy subjects. The capillary diameter can be slightly enlarged, but it does not have a diagnostic value. ${ }^{27}$ In primary RP patients, Bukhari et al. ${ }^{28}$ and Anderson et al. ${ }^{29}$ found enlarged capillary loops when compared with healthy subjects, which suggests minimal microvascular abnormalities. In an own study, nonsignificant dilation of capillary loops was detected by the software for quantitative assessment in patients with primary RP. ${ }^{15}$ The appearance of an abnormal nailfold capillary pattern is the best predictor of transition of primary RP into secondary RP in connective tissue disease with positive predictive value of $47 \%$ vs $30 \%$ positive predictive value of antinuclear antibodies. ${ }^{30}$

Maricq et al. found components of the scleroderma type capillaroscopic pattern in a group of diseases from the scope of scleroderma-spectrum disorders such as mixed-connective tissue disease, undifferentiated connective tissue disease, overlap syndromes, dermatomyositis - the so-called scleroderma-like capillaroscopic pattern. ${ }^{22,31}$ Scleroderma-like capillaroscopic pattern is found in about $50-65 \%$ of MCTD patients, which is significantly lower compared with the frequency of microvascular changes in SSc. ${ }^{32}$

Scleroderma-like capillaroscopic pattern in SLE was reported to vary between 2 and $9 \% 14,22,33,34$ and slightly higher as reported by Furtado $-15 \%{ }^{35}$. An association between presence of sclerodermalike capillaroscopic pattern and anti-U1-RNP antibodies has been observed. This stimulated the hypothesis that it could be manifestation of an overlap syndrome with SSc. In an own study, scleroderma-like pattern was observed in $13.3 \%$ of the examined 30 patients with SLE (4/30). In all 
the patients with scleroderma-like capillaroscopic finding, high immunologic activity was found, but signs for overlap with other connective tissue disease were not present. In two out of four patients with such capillaroscopic findings a vasculitis of peripheral vessels was evident. Anti-RNP antibody was positive in all but one patient with secondary RP without vasculitis of peripheral vessels. ${ }^{15,16} \mathrm{In}$ conclusion, scleroderma-like capillaroscopic pattern may be observed in patients with SLE with active vasculitis of peripheral vessels as well as in cases with secondary RP, in the presence of high immunologic activity without evidence of overlap with SSc or other connective tissue disease.

Nagy et al. did not find scleroderma-like capillaroscopic pattern in 14 patients with RA. ${ }^{14}$ In a previous study that included 62 RA with and without RP, a scleroderma-like pattern was observed in $14.5 \%$ (9/62), ( 2 males and 7 females). In one of these cases, an overlap of RA with SLE, secondary RP and secondary vasculitis was found. In the rest, 8/9 patients, no overlap with other connective tissue disease was evident. In all RA patients with scleroderma-like capillaroscopic pattern (9/9), a secondary RP was present, and in 2/9 - a secondary vasculitis. This suggests that scleroderma-like capillaroscopic pattern may be observed in RA patients with secondary RP and cases associated with vasculitis of peripheral vessels although with low frequency and its presence is not obligatorily associated with overlap syndromes. Similar findings have not been reported by other researchers in the current rheumatologic literature..$^{15,36}$

In cases of paraneoplastic scleroderma-like condition with RP associated with pulmonary cancer and 2 patients with paraneoplastic DM and RP in the context of pulmonary and thyroid cancer respectively, we were the first to report the absence of differences between capillaroscopic changes in paraneoplastic rheumatic conditions and the respective idiopathic rheumatic diseases..$^{15,37}$

The development of pathologic capillaroscopic changes requires time, which should be considered for the intervals of follow-up in these patients, that is about 6 months or shorter if clinical deterioration occurs..$^{15}$

\section{SKIN THERMOMETRY AND THERMOGRAPHY}

Finger skin temperature is considered a useful physiological parameter to evaluate the response of the digital vessels to cold challenge. The use of skin thermometry to assess peripheral vessels and their reactivity is based on the assumption that finger skin temperature depends on the rate of blood flow through the digit that is valid only under standardized laboratory conditions. Limitation of the finger skin thermometry is its dependence not only on the digital blood flow but also on environmental factors such as room temperature, air velocity, and humidity. ${ }^{38}$

Contrary to the skin thermometry that measures temperature at a single point, the infrared thermography is a method that provides a colour image of the surface temperature using a thermal camera. It is suggested that the skin temperature is representative of the underlying blood flow that involves both muscle and skin perfusion. ${ }^{7}$

In the diagnostic workup of RP patients, thermography is mainly used for dynamic testing of patients' response to cold challenge. The assessed parameters are basal temperature prior to cold provocation, temperature immediate after the cold challenge, the maximum temperature recovery rate, the time between the end of the cold challenge to the onset of rewarming, recovery index (the ratio between temperature increase and initial temperature decrease $\times 100 \%){ }^{39}$

A distal-dorsal difference of $>1{ }^{\circ} \mathrm{C}$ between the fingertips and the dorsum of the hand, (fingers cooler) in any finger evaluated via thermography was found to inherit a positive predictive value of $70 \%$, and a negative predictive value of $82 \%$, in identifying the patient with RP secondary to SSc thus aiding the prediction of SSc in patients with RP. ${ }^{40}$

\section{THERMOGRAPHY AND COLD PROVOCATION TEST}

O'Reilly D. et al. (1992) compared the cold challenge responses in 16 patients with primary RP, 20 patients with SSc and secondary RP and 21 healthy subjects via quantitative computed thermography that provides temperature recovery curves. The assessed parameters were as follows: basal temperature prior to cold provocation $\left(\mathrm{T}_{\text {pre }}{ }^{\circ} \mathrm{C}\right)$, temperature immediate after the cold challenge $\left(\mathrm{T}_{0}{ }^{\circ} \mathrm{C}\right)$. In addition, the maximum temperature recovery rate $\left(\mathrm{G}_{\max }-{ }^{\circ} \mathrm{C} /\right.$ minute) and the time at which this occurred $\left(\mathrm{T}_{\mathrm{lag}}\right)$ were measured that represented the lag phase from cold provocation until the rewarming began. At 1 , 5,10 , and 15 minutes after cold challenge, an index of percentage recovery was calculated and the maximum observed recovery index was assessed (\%) that is the ratio between temperature increase and initial temperature decrease $\mathrm{x} 100 \%$. The basal 
temperature $\left(\mathrm{T}_{\text {pre }}{ }^{\circ} \mathrm{C}\right)$ and the temperature immediate cold challenge $\left(\mathrm{T}_{0}^{\circ} \mathrm{C}\right)$ were found to be significantly lower in both patients with primary RP and secondary RP in SSc in comparison with healthy subjects without significant difference between the groups of primary and secondary RP for both parameters. In healthy controls, there was a short lag phase followed by a rapid to above basal levels, which was proved by the significant differences in $T_{\text {lag }}, G_{\max }$ and the recovery index with the other two groups. In patients with primary RP, there was a longer lag phase with slower and incomplete recovery. In patients with SSc and secondary RP, there was a prolonged period without significant temperature recovery by 15 minutes after the cold challenge. Although the dynamic parameters $\left(\mathrm{G}_{\max }\right.$, recovery index) were more powerful discriminants between primary and secondary RP as compared with $T_{\text {pre }}$ and $\mathrm{T}_{0}$, the difference did not reach statistical significance.

In conclusion, the quantitative thermography and the analysis of rewarming curves measures the response of RP patients to cold challenge that is characterized with slower temperature recovery after a longer delay. ${ }^{39}$

However, thermography is not currently an established technique for differential diagnosis of primary and secondary RP due to lack of significant discriminative values.

\section{LASER DOPPLER FLOWMETRY AND LASER DOPPLER IMAGING}

Laser Doppler flowmetry is a non-invasive method for assessment of cutaneous microcirculatory flow using laser light. The technique depends on the Doppler broadening of laser light scattered by moving particles and gives information about moving particle density and flux. Flux is the parameter used to express blood flow and the average velocity is calculated by dividing flux to density. Helium-neon lasers with small probes are most commonly used with a wavelength of $632.8 \mathrm{~nm}$ (red light). The depth of penetration of skin by the laser beam depends on the equipment and is usually about $1 \mathrm{~mm}$ with surface area about $1 \mathrm{~mm}^{2}$, resulting in a theoretical total measured tissue volume of $1 \mathrm{~mm}^{3}$. The method includes assessment of blood flow of both the superficial nutritional capillaries and the deeper thermoregulatory vessels. The tissue penetration of green light with wavelength $543.5 \mathrm{~nm}$ is about $60 \%$ of that of red light with over $20 \%$ greater absorption. Using laser Doppler flowmetry at the two wavelengths could provide separate evaluation of the deeper lying thermoregulatory component of blood flow and the more superficial nutritional component of the blood flow. ${ }^{7,41-44}$ A significant disadvantage of the technique is the large site-to-site signal variation. Even a minor change in position or orientation of the probe can lead to significant variation in the estimation of blood flow. Thus, two signals from two different adjacent sites vary making the technique poorly reproducible, even when protocols incorporate dynamic testing. The direct contact of the probe with the skin causing mild compression might itself influence blood flow. ${ }^{7}$

Laser Doppler imaging is a new instrumental technique that measures flux over a greater area not in a single point via scanning laser Doppler equipment. It offers the advantage of not requiring direct contact between a probe and the skin. Laser Doppler images represent a pictorial flux map. Laser Doppler imaging equipment is currently mainly a research tool that is available in few specialized centres.

Laser Doppler investigation could be applied together with administration of drugs that mediate evaluation of endothelium-dependent and endothelium-independent vasodilation. A lot of research has focused on the early detection of endothelial dysfunction in humans that is characterized with reduction of the bioavailability of several active vasodilators e.g., nitric oxide with a concurrent increase in bioavailability of endothelium-derived contracting factors such as endothelin-1, causing an overall reduction in endothelium-dependent vasodilation.

Measurement of the cutaneous perfusion by laser Doppler flowmetry accompanied by iontophoresis of acetylcholine and sodium nitroprusside as a measure of endothelial function is a noninvasive test for assessment of endothelial function. Iontophoresis is the introduction of ions of soluble salts into the tissues of the body by means of a direct electrical current.

Endothelial-dependent vasodilation is induced after administration via iontophoresis of acetylcholine (methacholine, bradykinin, and substance $P$ could also be used). Acetylcholine is a standard substance that mediates vasodilatation via endothelial-dependent production of $\mathrm{NO}$ and/or prostanoids with a possible accessory role played by endothelium-derived hyperpolarizing factor. Endothelial-independent vasodilation is induced after administration of sodium nitroprusside that is a donor of NO and reacts with tissue sulfhydryl 
groups under physiologic conditions to produce NO directly and thereby stimulate smooth muscle cells relaxation acting equally on all arterial and venous vessels. Compromised vasodilation after stimulation with acetylcholine with preserved response to sodium nitroprusside is an indicator for endothelial dysfunction. ${ }^{45}$

Impaired microvascular response measured by laser Doppler iontophoresis has been demonstrated in essential hypertension, diabetes, systemic sclerosis. ${ }^{46-48}$

\section{FINGER SYSTOLIC BLOOD PRESSURE}

The Nielsen test to diagnose RP (introduced by Nielsen, 1977) represents a measurement of finger systolic blood pressure (FSBP) after cold provocation. Local cold provocation test may be performed (cooling the hands for 5 minutes at 15,10 and $6^{\circ} \mathrm{C}$ ) as well as combined local plus whole body cooling. FSBP is measured with an inflatable plastic cuff of the proximal phalanx of the thumb or at the middle phalanx of the fingers from $2^{\text {nd }}$ to $5^{\text {th }}$. The examination provides information about digital arteries. In healthy individuals, at standard temperature, the FSBP is identical with the blood pressure measured at the brachial artery. The diurnal and between-day variations are between 5 and $10 \%$ in healthy people, which makes the method highly reproducible. Measurement of FSBP after cold provocation leads to drop of FSBP only in RP due to increased blood vessel tone that reflects the cold-induced vasospasm. In healthy individuals, the strongest decrease of FSBP after 5-minutes cold provocation test during the next 15 minutes of evaluation is $68 \%$ from the initial values. An RP attack was verified as a zero blood FSBP. However, obtaining a zero FSBP in laboratory conditions has been found difficult to achieve. The gap of FSBP\% between $68 \%$ of the starting values and zero was accepted to detect an abnormal reaction in patients with anamnestic RP but no provoked RP attack, subjects with exaggerated subclinical cold reaction but without anamnestic $\mathrm{RP}$, and subjects with a false-positive test. Falsenegative results have been observed in some cases of milder forms of RP. ${ }^{49}$

\section{PlethysmogRaPhy}

Most types of plethysmography rely on volume change. It may be performed with venous occlusion placing a blood pressure cuff around the proximal phalanx of the finger and inflated above venous pressure but below arterial pressure. This leads to increased finger volume because the venous return is blocked, and the degree of the finger swelling immediately after occlusion reflects the blood flow into the finger.

Maricq et al. found different values of the mean blood flow measured by venous occlusion plethysmography in patients with primary RP, "cold sensitive" subjects, patients with SSc spectrum disorders and controls, but the difference was not statistically significant. ${ }^{50}$

Plethysmography (without occlusion) can be used to detect presence or absence of arterial blood flow. A strain gauge placed around the distal phalanx measures the pulsatile changes in volume that indicates patent vessels and can be used detect digital systolic opening pressure. ${ }^{7}$

\section{DOPPLER ULTRASOUND}

High resolution ultrasound scanners allow detection of arterial pulses, and therefore artery patency and is indicated in cases of suspicion of structural digital artery disease. Visualisation and measurement of digital arteries diameter and of arterial blood velocity could facilitate the quantifying of structural artery disease, and vasospasm. In patients with RP, dynamic testing is studied in evaluation of vasospasm but it remains mainly a research tool. ${ }^{7}$ Naidu et al. also reported that the degree of reduction in digital artery diameter after a standard cold challenge could differentiate between patients with RP and controls, although the technique did not discriminate between primary and secondary RP. ${ }^{7,51}$

\section{ANGIOGRAPHY}

Conventional angiography and magnetic resonance angiography (MRA) of the peripheral arteries could provide information about vascular anatomy prior to surgery, for diagnosing of pathology of peripheral blood vessels e.g., emboli, thrombosis, vasculitides. ${ }^{52}$ The findings from angiography in patients with primary and secondary RP are not pathognomonic in most of the cases. Angiography is indicated in patients with clinical signs of critical ischemia, unilateral limb involvement for diagnosing emboli, thrombosis, atheromatous plaque, some forms of vasculitides.

MRA has been used with and without intravenous injection of contrast media - gadolinium as a safe, reliable, and accurate technique for evaluation of vascular pathology of the hand. MRA allows accurate evaluation of arterioles and is also well suited for evaluating the extent of venous lesions. ${ }^{53}$

The following vascular lesions were found at MRA in 38 SSc patients by Allanore et al. (2007): 
proper digital artery that did not reach the first phalanx, thin arteries, one or more avascular areas, abnormal or missing venous return. Of note, patients with SSc who had $\geq 4$ proper digital arteries that did not reach the first phalanx more frequently had digital ulcers. The study demonstrates the presence of substantial vascular involvement in SSc that involve both arterial and venous vessels of small caliber as well as the microcirculation. ${ }^{53}$

WHICH INSTRUMENTAL METHOD TO CHOOSE?

The instrumental methods for vascular assessments provide the following information:

- nailfold capillaroscopy - the only method for morphological assessment of nutritive capillaries in the nailfold area;

- laser-Doppler flowmetry and laser-Doppler imaging are methods for functional assessment of microcirculation;

- measurement of finger systolic blood pressure and Doppler ultrasound - methods for assessment of peripheral arteries including digital arteries;

- conventional angiography and magnetic resonance angiography - a method that could be used for evaluation of peripheral arteries including digital arteries;

- thermography and plethysmography - reflect both blood flow in peripheral arteries and microcirculation.

Doppler ultrasound is a standard technique for assessment of the structural arterial pathology in patients with connective tissue disease. The nailfold capillaroscopy is also already available in the majority of centres of rheumatology specialized in diagnosis and differential diagnosis of peripheral ischaemic syndromes. Moreover, the abnormal capillaroscopic pattern in $\mathrm{SSc}$ is validated as diagnostic criterion of the disease, while the absence of signs of microangiopathy is crucial for the diagnosis of the idiopathic primary RP. The other imaging techniques are available only in a limited number of centres that possess sophisticated equipment used mainly in research projects.

It should be considered that some of the instrumental techniques provide opportunity for functional vascular assessment and most involve dynamic testing. Many of these require further validation to assess their sensitivity and specificity in differentiation of primary and secondary forms of RP in rheumatic diseases. In addition, apart from the exact used protocol and equipment, functional assessment is influenced also by patient's degree of sympathetic tone during examination, the stage of the menstrual cycle in women, patient's age and gender. In addition, the lack of standardization of the testing conditions e.g., room temperature, duration of acclimatization as well as the severity and duration of the dynamic cold challenge does not permit comparison of the results from the different studies. ${ }^{7}$

Two case reports are presented to better demonstrate the opportunities of some of the instrumental techniques in differential diagnosis of peripheral ischaemic syndromes.

\section{CASE REPORT 1}

A 55-year-old woman diagnosed with SLE presented at consultation with severe pain in the right lower extremity distal to knee joint that appeared 3 days before examination. The diagnosis was established 1 year ago with symmetric polyarthritis, skin, haematologic and immunologic involvement, serositis and secondary $R P$. She had been treated with corticosteroids and methotrexate. The physical examination revealed erythematous lesions at the neck, symmetric arthritis of the hands, mild RP of hands and feet, preserved symmetric arterial pulsations. During the dynamic follow-up in 3-week period she developed vasculitis of peripheral vessels of hands and feet with the respective skin lesions. The laboratory investigations revealed normal values of parameters of peripheral blood count e.g., red blood cells - $4.48 \mathrm{~T} / \mathrm{l}$, haemoglobin - 146 $\mathrm{g} / \mathrm{l}$, haematocrit - 43.5, MCV $97.3 \mathrm{fl}$, white blood cells, $11.8 \mathrm{G} / \mathrm{l}$ with differential count within normal range, platelets - $295 \mathrm{G} / \mathrm{l}$, erythrocyte sedimentation rate - $30 \mathrm{~mm} / \mathrm{hour}, \mathrm{C}$-reactive protein - 1.5 , alkaline phosphatase and transaminases - within normal values.

Immunological profile with examination of autoantibodies via ELISA method included the following positive tests - anti-dsDNA - $125.3(<25)$, anti-Sm - $21.6(<7.5)$, anti-cardiolipin $\operatorname{Ig} G-56.77(<48)$, anti-beta2-glycoprotein-negative $(<5)$. Fractions of serum complement were within normal values: $C 3$ - 1.914 (0.61-2.09), C4 - 0.452 (0.122-0.495). The disease manifestation was categorized as secondary vasculitis of peripheral vessels and secondary antiphospholipid syndrome. The therapy included methylprednisolone $-1 \mathrm{mg} / \mathrm{kg}$, heparin - 1000U/ hour in 24-hour infusion, opioid analgesics for the severe ischaemic pain. In the next 3-4 days, the patient presented with necrosis of toe of the right foot, necrotic lesion of the right lower leg that evolved into ulcer (Figs 2, 3). 


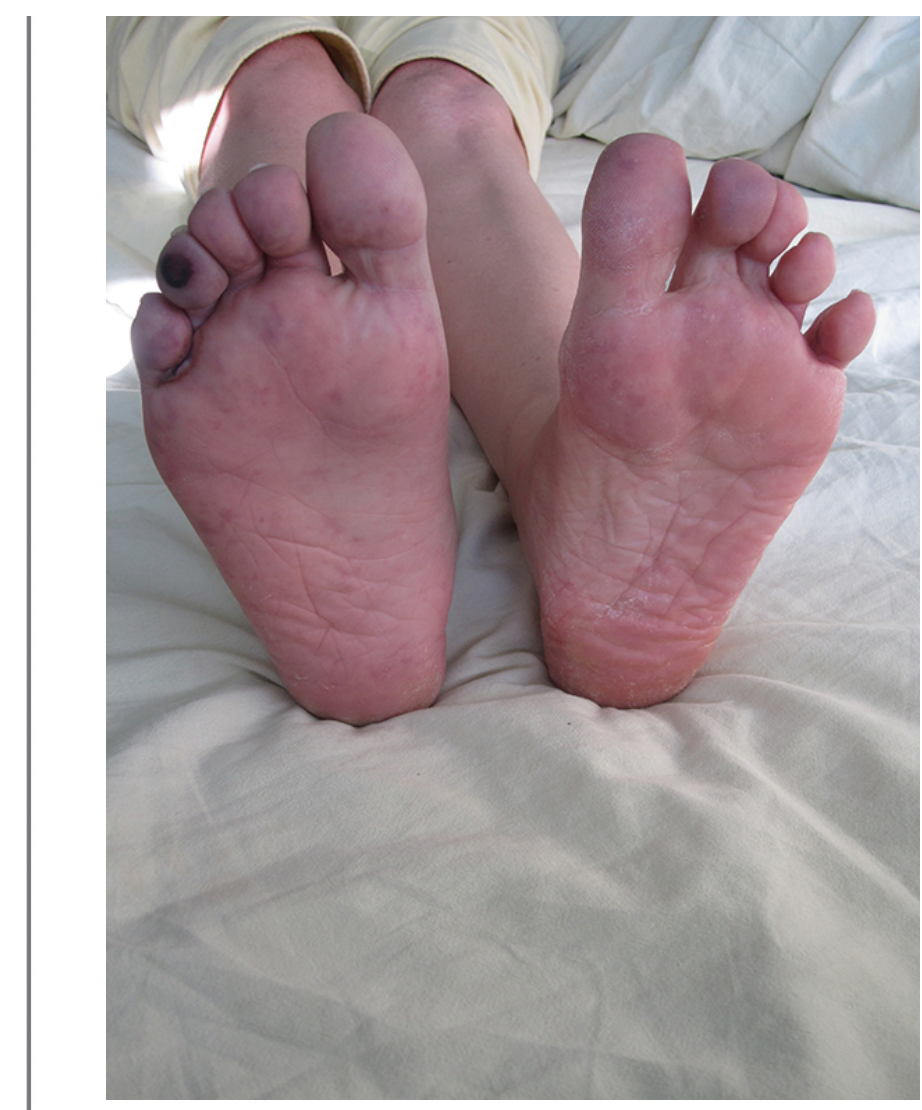

Figure 2. Blue toe syndrome lesion of the $4^{\text {th }}$ toe of right foot is demonstrated in a patient with systemic lupus erythematosus, antiphospholipid syndrome and thrombosis of peripheral artery (case 1).

Pulsation of the vessels distal to right popliteal artery were absent at physical examination. Doppler ultrasound demonstrated a lack of signal at peripheral arteries of the right lower extremity distal to the right popliteal artery. Angiography

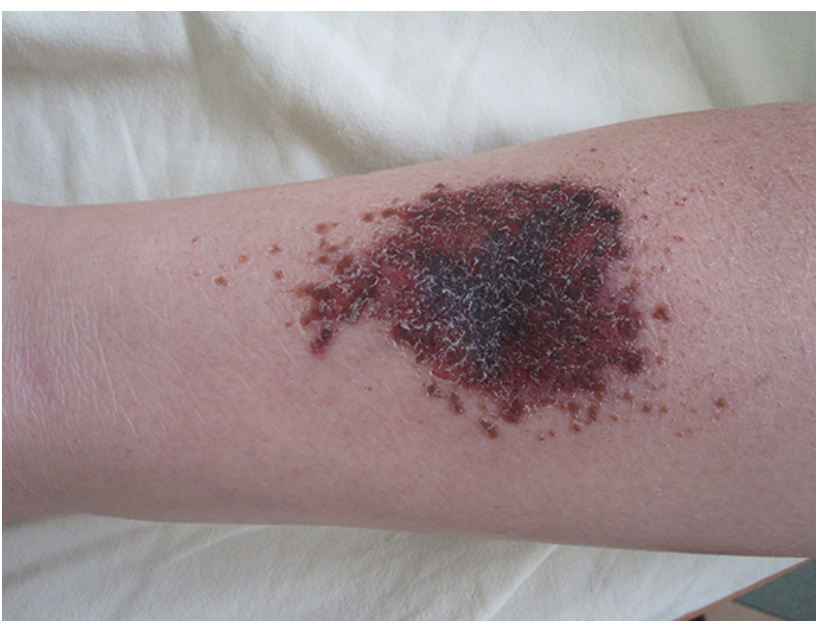

Figure 3. Necrotic lesion of the lower extremity in the context of peripheral artery thrombosis (case 1). was performed that showed thrombosis at the level of right popliteal artery. The patient underwent two operations at a 3-day interval due to relapse; thrombectomy was performed. Perioperative treatment included methylprednisolone - $1 \mathrm{mg} / \mathrm{kg}$, immunovenin - 3×20 ampules intravenously every other day, antibiotic, heparin that was switched on acenocoumarol in 1 month, vasodilators, local antiseptic care for the ulcer. After ulcer healing in a period of 3.5 months a monthly pulse-therapy with cyclophosphamide and methylprednisolone was initiated that lead to good control of disease activity without relapse of the symptoms (Fig. 3).

\section{CASE REPORT 2}

A 34-year-old woman presented with 3-year history of tri-phasic RP, which had worsened in the previous year in terms of frequency, duration and the severity of vasospastic attacks. RP was located at the fingers and toes, being more severe at the hands without history for digital ulcers. At physical examination, no puffy fingers, skin thickening or other abnormal findings suggestive of secondary $R P$ were found. No concomitant diseases were present. At capillaroscopic examination, scleroderma type capillaroscopic pattern, "early" phase was observed. Numerous dilated and giant capillaries, without haemorrhages, preserved distribution, normal mean capillary density were present (Fig. 4). The routine laboratory investigations showed normal values of parameters of peripheral blood count, e.g., red blood cells - $4.24 \mathrm{~T} / \mathrm{l}$, haemoglobin - $137 \mathrm{~g} / \mathrm{l}$, haematocrit - 39.7, MCV $93.8 \mathrm{fl}$, white blood cells - $7.0 \mathrm{G} / \mathrm{l}$, platelets, $246 \mathrm{G} / \mathrm{l}$. Erythrocyte

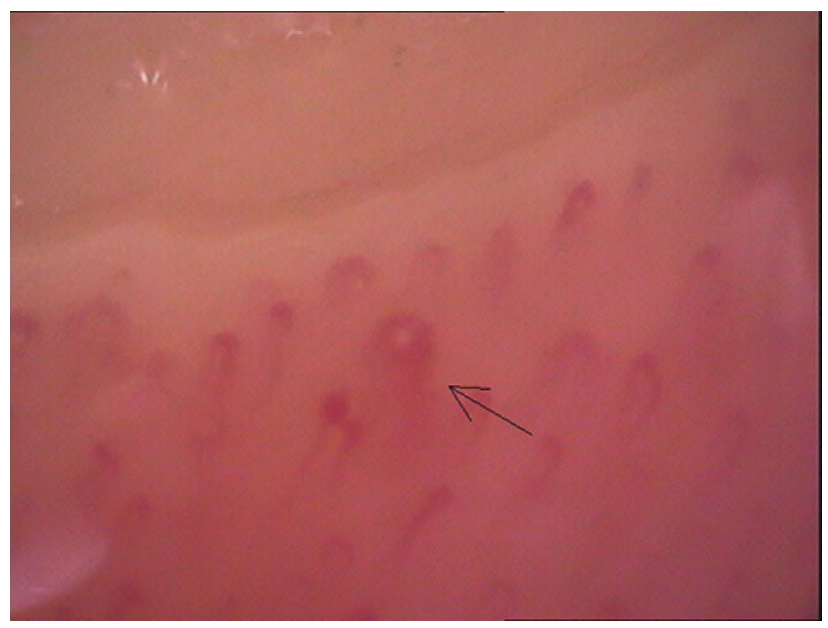

Figure 4. Scleroderma type capillaroscopic pattern, early phase: presence of dilated and single giant capillary loop (arrow) (case 2). 
sedimentation rate was slightly elevated, $55 \mathrm{~mm} / \mathrm{hour}$, the major parameters of biochemistry (creatinine, transaminases) were within normal values.

The test for ANA was negative (1:40, direct immunofluorescence). The ELISA tests for scleroderma-specific autoantibodies e.g., anti-centromere and anti-Scl-70 were negative.

The diagnosis of "pre-scleroderma" was made. Treatment with a vasodilator and antiplatelet drugs was initiated and closer follow-up by rheumatologist was recommended. In a 3-month period oedema of fingers was present and in an 8-month period skin thickening of the entire upper and lower extremities, chest, abdomen, back and face was evident. Thus, the diagnosis was modified to SSc with diffuse cutaneous involvement. Therapy with d-penicillamine, vasodilators (calcium channel blockers, ACE-inhibitor), antiplatelet agent was initiated. In a 1-year period, the skin involvement improved significantly and after 3 years it was evident only at the hands, feet and face. ANA test remained permanently negative during the followup. This case report confirms the role of nailfold capillaroscopy for very early diagnosis of SSc. It also could lead to possible better disease evolution in cases of early treatment administration that remains to be confirmed.

\section{CONCLUSIONS}

In cases of abrupt onset of peripheral ischaemia (hours, days, weeks), signs of critical ischemia, in cases of unilateral or lower limb involvement - dynamic physical examination should be performed, Doppler ultrasound of peripheral vessels and angiography are indicated. Most common causes for such clinical picture are as follows:

- antiphospholipid syndrome;

- hyperviscosity syndrome - myeloproliferative syndromes, cryoglobulinemia, cryofibrinogenemia; - mimickers of vasculitides (peripheral atherosclerosis, atherosclerosis with cholesterol emboli - after coronarography, during anticoagulation therapy), emboli from cardiac or aortic origin (for example in infective endocarditis), neoplasms.

Nailfold capillaroscopy is the only method for morphological assessment of nutritive capillaries in the nailfold area. Its main role is to provide differential diagnosis between primary and secondary RP. In rheumatology, capillaroscopic changes are diagnostic for SSc. The appearance of abnormal capillaroscopic pattern for development of connective tissue disease possesses high predictive value of $47 \%$ that is higher than antinuclear antibodies. The development of pathologic capillaroscopic changes requires time, which should be considered for the intervals of follow-up in these patients that is about 6 months. Nailfold capillaroscopy is indicated in all patients with symptoms of RP. If signs of microangiopathy are absent, the patients should undergo regular clinical, capillaroscopic, laboratory and immunological follow-up at a 6-month interval or in case of clinical deterioration.

\section{REFERENCES}

1. Cortes S, Cutolo M. Capillaroscopic patterns in rheumatic diseases. Acta Reum Port 2007;32:29-36.

2. Ho M, Belch JJ. Raynaud's Phenomenon: State of the Art 1998. Scand J Rheumatol 1998;27:319-22.

3. Carrol GJ, Withers K, Bayliss CE. The prevalence of Raynaud's syndrome in rheumatoid arthritis. Ann Rheum Dis 1981;40:567-70.

4. Müller-Ladner U. Raynaud's phenomenon and peripheral ischemic syndromes. 1st ed, Bremen: UNI-MED Verlag AG; 2008, pp. 36-41.

5. Wigley FM. Raynaud's phenomenon. N Engl J Med 2002;347(13):1001-8.

6. Hirschmann JV, Raugi GJ. Blue (or purple) toe syndrome. J Am Acad Dermatol 2009;60(1):1-20.

7. Herrick A, Clark S. Quantifying digital vascular disease in patients with primary Raynaud's phenomenon and systemic sclerosis. Ann Rheum Dis 1998;57(2):70-78.

8. Block JA, Sequeira W. Raynaud's phenomenon. Lancet 2001;357(9273):2042-8.

9. Seibold JR, Steen VD. Systemic sclerosis. In: Klippel JH, Dieppe PA. Rheumatology. London: Mosby; 1994: 6.8.- 6.11.

10. Hachulla E, Clerson P, Launay D, et al. Natural history of ischemic digital ulcers in systemic sclerosis: single-center retrospective longitudinal study. J Rheumatol 2007;34:2423-30.

11. La Montagna G, Baruffo A, Tirri R, Buono G, Valentini G. Foot involvement in systemic sclerosis: a longitudinal study of 100 patients. Semin Arthritis Rheum 2002;31(4):248-55.

12. Kirou KA, Crow MK. Raynaud's phenomenon. In: Paget SA, et al. Manual of rheumatology and outpatient orthopedic disorders: diagnosis and therapy. 4th ed., Philadelphia, Lippincot Williams \& Willkins 2000, 82-7.

13. Smolen JS, Steiner G. Mixed connective tissue disease: to be or not to be? Arthritis Rheum 1998;41(5):768-77.

14. Nagy Z, Czirjac L. Nailfold digital capillaroscopy in 447 patients with connective tissue disease and Raynaud's disease. J Europ Acad Dermatol Venerol 2004;18:62-8.

15. Lambova $\mathrm{S}$. The role of capillaroscopy in rheumatology. [Dissertation] Justus Liebig University, Gies- 
sen, Germany, (2011)

16.Lambova SN, Müller-Ladner U. Capillaroscopic pattern in systemic lupus erythematosus and undifferentiated connective tissue disease: what we still have to learn? Rheumatol Int 2013;33(3):689-95.

17. Le Roy EC, Medsger TA Jr. Raynaud's phenomenon - a proposal for classification. Clin Exp Rheumatol 1992;10:485-8.

18. Grassi W, Blasetti P, Core P, Cervini C. Raynaud's phenomenon in rheumatoid arthritis. Br J Rheumatol 1994;33:139-41.

19. Carrol GJ, Withers K, Bayliss CE. The prevalence of Raynaud's syndrome in rheumatoid arthritis. Ann Rheum Dis 1981;40:567-70.

20. Saraux A, Allain J, Guedes C, Baron D, Youinou P, Le Goff P. Raynaud's phenomenon in rheumatoid arthritis. Br J Rheumatol 1996;35(8):752-4.

21. Cutolo M, Sulli A, Secchi ME, Olivieri M, Pizzorni C. The contribution of capillaroscopy to the differential diagnosis of connective autoimmune diseases. Best Pract Res Clin Rheumatol 2007;21(6):1093-108.

22. Maricq HR, Le Roy EC, D'Angelo WA, Medsger TA Jr, Rodnan GP, Sharp GC, Wolfe JF. Diagnostic potential of in vivo capillary microscopy in scleroderma and related disorders. Arthritis Rheum 1980;23(2):183-189.

23. Cutolo M, Sulli A, Pizzorni C, Accardo S. Nailfold videocapillaroscopy assessment of microvascular damage in systemic sclerosis. J Rheumatol 2000;27(1):155-60.

24.Le Roy EC, Medsger TA Jr. Criteria for the classification of early systemic sclerosis. J Rheumatol 2001;28:1573-6.

25.van den Hoogen F, Khanna D, Fransen J, Johnson SR, Baron M, Tyndall A, et al. 2013 classification criteria for systemic sclerosis: an American college of rheumatology/European league against rheumatism collaborative initiative. Ann Rheum Dis 2013;72(11):1747-55.

26.van den Hoogen F, Khanna D, Fransen J, Johnson SR, Baron M, Tyndall A, et al. 2013 classification criteria for systemic sclerosis: an American College of Rheumatology/European League against Rheumatism collaborative initiative. Arthritis Rheum 2013;65(11):2737-47.

27. Bollinger A, Fagrell B. Clinical capillaroscopy - a guide to its use in clinical research and practice. Toronto: Hogrefe \& Huber Publishers; 1990:pp. 1-123.

28. Bukhari M, Hollis S, Moore T, Jayson MI, Herrick AL. Quantitation of microcirculatory abnormalities in patients with primary Raynaud's phenomenon and systemic sclerosis by videocapillaroscopy. Rheumatology (Oxford) 2000;39(5):506-12.

29. Anderson ME, Allen PD, Moore T, Hillier V, Taylor CJ, Herrick AL. Computerized nailfold videocapillaroscopy - a new tool for assessment of Raynaud's phenomenon. J Rheumatol 2005;32:841-8.

30. Spencer-Green G. Outcomes in primary Raynaud phenomenon: a meta-analysis of the frequency, rates, and predictors of transition to secondary diseases. Arch Intern Med 1998; 158(6):595-600.

31. Maricq HR, Harper FE, Khan MM, et al. Microvascular abnormalities as possible predictors of disease subsets in Raynaud phenomenon and early connective tissue disease. Clin Exp Rheumatol 1983;1(3):195-205.

32. de Holanda Mafaldo Diógenes A, Bonfá E, Fuller R, Correia Caleiro MT. Capillaroscopy is a dynamic process in mixed connective tissue disease. Lupus 2007;16(4):254-8.

33. Bergman R, Sharony L, Schapira D, et al. The handheld dermatoscope as a nail-fold capillaroscopic instrument. Arch Dermatol 2003;139:1027-30.

34. Kabasakal Y, Elvins DM, Ring EF, McHugh NJ. Quantitative nailfold capillaroscopy findings in a population with connective tissue disease and in normal healthy controls. Ann Rheum Dis 1996;55:507-12.

35. Furtado RNV, Pucinell MLC, Cristo VV, Andrade LEC, Sato EI. Scleroderma-like nailfold capillaroscopic abnormalities are associated with anti-U1RNP antibodies and Raynaud's phenomenon in SLE patients. Lupus 2002; 11(1):35-41.

36.Lambova SN, Müller-Ladner U. Capillaroscopic pattern in inflammatory arthritis. Microvasc Res 2012;83(3):318-22.

37.Lambova S, Müller-Ladner U. Capillaroscopic pattern in paraneoplastic Raynaud's phenomenon. Rheumatol Int 2013;33(6):1597-9.

38. Bovenzi M. Finger thermometry in the assessment of subjects with vibration-induced white finger. Scand J Work Environ Health 1987;13(4):348-351.

39. O'Reilly D, Taylor L, el-Hadidy K, Jayson MI. Measurement of cold challenge responses in primary Raynaud's phenomenon and Raynaud's phenomenon associated with systemic sclerosis. Ann Rheum Dis 1992;51(11):1193-6.

40. Anderson ME, Moore TL, Lunt M, Herrick AL. The 'distal-dorsal difference': a thermographic parameter by which to differentiate between primary and secondary Raynaud's phenomenon. Rheumatology (Oxford) 2007;46(3):533-8.

41. Gush RJ, King TA. Discrimination of capillary and arteriovenular blood flow in skin by laser Doppler flowmetry. Med Biol Eng Comput 1991;29:387-92.

42. Yvonne-Tee GB, Rasool AH, Halim AS, Rahman AR. Noninvasive assessment of cutaneous vascular function in vivo using capillaroscopy, plethysmography and laser-Doppler instruments: its strengths and weaknesses. Clin Hemorheol Microcirc 2006;34(4):457-73.

44.Lenasi H. Assessment of Human Skin Microcirculation and Its Endothelial Function Using Laser Doppler Flowmetry. In: Erondu OF. Medical Imaging. Rijeka: InTech InTech; Croatia 2011, pp. 271-296. 45. Turner J, Belch JJ, Khan F. Current concepts in as- 
sessment of microvascular endothelial function using laser Doppler imaging and iontophoresis. Trends Cardiovasc Med 2008;18(4):109-116.

46.Farkas K, Kolossváry E, Járai Z, et al. Non-invasive assessment of microvascular endothelial function by laser Doppler flowmetry in patients with essential hypertension. Atherosclerosis 2004;173:97-102.

47. Elhadd TA, Khan F, Kirk G, et al. Influence of puberty on endothelial dysfunction and oxidative stress in young patients with type 1 diabetes. Diabetes Care 1998;21:1990-1996.

48. Anderson ME, Moore TL, Lunt M, Herrick AL. Digital iontophoresis of vasoactive substances as measured by laser Doppler imaging--a non-invasive technique by which to measure microvascular dysfunction in Raynaud's phenomenon. Rheumatology (Oxford) 2004; 43(8):986-91.
49. Olsen N. Standardization of finger systolic blood pressure (FSBP) cooling tests Environ Health Prev Med 2005;10(6):360-5.

50. Maricq HR, Weinrich MC, Valter I, Palesch YY, Maricq JG. Digital vascular responses to cooling in subjects with cold sensitivity, primary Raynaud's phenomenon, or scleroderma spectrum disorders. J Rheumatol 1996;23:2068-78.

51. Naidu S, Baskerville PA, Goss DE, Roberts VC. Raynaud's phenomenon and cold stress testing: a new approach. Eur J Vasc Surg 1994;8(5):567-73.

52. Connell DA, Koulouris G, Thorn DA, Potter HG. Contrast-enhanced MR angiography of the hand. Radiographics 2002;22(3):583-599.

53. Allanore Y, Seror R, Chevrot A, Kahan A, Drapé JL. Hand vascular involvement assessed by magnetic resonance angiography in systemic sclerosis. Arthritis Rheum 2007;56(8):2747-54.

\section{Место капилляроскопии ногтевого ложа среди инструментальных методов оценки некоторых периферических ишемических синдро- мов в ревматологии}

\section{Севдалина Н. Ламбова}

Кафедра пропедевтики внутренней медицины, Факультет медицины, Медицинский университет, Пловдив, Болгария

\section{Для корреспонденции:}

Севдалина Ламбова, Кафедра пропедевтики внутренней медицины, Факультет медицины, Медицинский университет, Пловдив, бул. Васила Априлова № 15A, 4002 Пловдив, Болгария E-mail: sevdalina_n@abv.bg Тел.: +359 889560104

Дата получения: 09 марта 2016 г. Дата приемки: 04 мая 2016 г. Дата публикации: 30 июнья 2016 r.

Ключевые слова: Феномен Рейно, синдром голубых пальцев, ревматические заболевания, микроциркуляция; капилляроскопия ногтевого ложа

Цитаты: Ламбова СН. Место капилляроскопии ногтевого ложа среди инструментальных методов оценки некоторых периферических ишемических синдромов в ревматологии. Folia Medica 2016;58(2);77-88, doi: 10.1515/folmed-2016-0011
Микро- и макроваскулярная патология представляет собой часто встречающееся явление в ряде обычных ревматических заболеваний. Вторичный феномен Рейно (RP) входит в число наиболее распространенных симптомов при наличии систематического склероза и некоторых других систематических аутоиммунных заболеваний, включая широкий дифференциальный диагноз. Необходимо его разграничение и от других васкулярных синдромов, таких как эмболия, тромбоз и др., некоторые из которых приводят к клиническому проявлению синдрома голубых пальцев.

В данной разработке рассматриваются инструментальные методы васкулярной диагностики.

Капилляроскопия ногтевого ложа представляет собой единственный метод в числе техник визуальной диагностики, который можно использовать для морфологической оценки питающих капилляров в области ногтевого ложа. Лазерная допплеровская флоуметрия и лазерное допплеровское исследование являются методами для функциональной диагностики микроциркуляции, в то время как такие методы, как термография и плетизмография отображают как состояние потока крови в периферических артериях, так и микроциркуляцию крови. С помощью метода допплеровской ультрасонографии и ангиографии визуализируются периферические артерии. Выбор подходящего инструментального метода основан на клиническом представлении. Основная роль капилляроскопии заключается в предоставлении дифференциального диагноза между первичным и вторичным RP. B ревматологии капилляроскопические изменения при наличии систематического склероза с недавних пор используются в качестве средства диагностики. Появление анормальных капилляроскопических признаков унаследует высокий предиктивный показатель развития заболеваний соединительной ткани, являющийся выше предиктивного показателя антиядерных антител. В случаях внезапного проявления периферической ишемии, клинических признаков критической ишемии, с односторонним вовлечением конечностей или с участием нижних конечностей, рекомендуется использование допплеровской ультрасонографии и ангиографии. Самой распространенной причиной подобной клинической картины, которую можно соотнести с ревматологической консультацией, являются антифосфолипидный синдром, имитирующие васкулит состояния, такие как атеросклероз с холестериновой эмболией и неоплазма. 